\title{
GAMBARAN STRES TENAGA KESEHATAN PADA MASA PANDEMI COVID-19
}

\author{
Nindia Pratitis ${ }^{1}$ Astri Haryanti ${ }^{2}$ Nur Ajeng Irma Hariyanti ${ }^{3}$ Elza Kusumawati $^{4}$ \\ E-mail:nindia@untag-sby.ac.id ${ }^{1}$ \\ Fakultas Psikologi Universitas 17 Agustus 1945, Surabaya ${ }^{1,2,3,4}$
}

\begin{abstract}
Abstrak
Covid-19 telah ditetapkan sebagai pandemi global. Kemunculan covid-19 memberikan dampak besar bagi banyak pihak. Kasus kejadian Covid-19 terus meningkat dari hari ke hari. Setiap harinya jumlah kasus positif covid selalu bertambah. Pihak yang paling terdampak dalam penanganan Covid adalah tenaga kesehatan. Para tenaga kesehatan yang berperan sebagai garda terdepan penanganan Covid-19 menghadapi berbagai macam tantangan baik resiko tertular penyakit, harus hidup terpisah dari keluarga, dan berbagai macam tantangan lainnya. Menindaklanjuti permasalahan tersebut, maka penelitian ini bertujuan untuk mengetahui gambaran stres tenaga kesehatan pada masa Pandemi Covid-19. Metode dalam penelitian ini adalah kuantitatif deskriptif, dengan partisipan 101 orang. Teknik sampling yang digunakan ialah convenience sampling. Pengumpulan data kuantitatif menggunakan skala depression anxiety stress scale (DASS-21). Hasil analisis data menunjukkan bahwa 67,3\% tenaga kesehatan yang menjadi responden dalam penelitian ini memiliki tingkat stres dalam kategori sedang, 17,9\% dalam kategori tinggi, dan 17,8\% dalam kategori rendah.
\end{abstract}

Kata kunci : Stres, Pandemi Covid 19, Tenaga Kesehatan

PENDAHULUAN

WHO telah menetapkan wabah virus corona jenis baru atau SARS-CoV2 penyebab COVID-19 sebagai pandemi global. Penetapan tersebut disampaikan langsung Direktur Organisasi Kesehatan Dunia (WHO) Tedros Adhanom Ghebreyesus dalam konferensi pers, Rabu (11/3/2020). Keputusan itu diambil seiring meningkatnya kasus di luar China hingga 13 kali lipat dan banyaknya negara yang terinfeksi. (Budiansyah, 2020).

Kasus kejadian Covid-19 terus meningkat dari hari ke hari. Setiap harinya jumlah kasus positif covid selalu bertambah. Pihak yang paling terdampak dalam penanganan Covid adalah tenaga kesehatan. Tenaga kesehatan menjadi garda terdepan dalam berinteraksi langsung dengan pasien Covid-19. Resiko tertular penyakit tersebut pada para tenaga kesehatan sangat besar. Hal itu kemudian diminimalisir dengan penggunaan alat perlindungan diri (APD) bagi para tenaga kesehatan. Penggunaan alat perlindungan diri (APD) juga menjadi tantangan tersendiri bagi tenaga kesehatan. Para tenaga kesehatan harus menggunakan APD di shift kerjanya selama kurang lebih 8 jam. Pengggunaan APD tersebut menyebabkan mereka kesulitan untuk makan, minum, dan buang air kecil. Terlebih lagi jumlah pasien yang terus bertambah dan jumlah tenaga kesehatan 
yang terbatas membuat mereka seringkali kekurangan waktu untuk mengurus diri sendiri (Melisa, 2020).

Bantuan alat perlindungan diri (APD) bagi para tenaga kesehatan terus diberikan namun masih saja ada tenaga kesehatan yang tetap tertular virus Covid19. Seperti halnya yang terjadi pada puluhan tenaga kesehatan di RSUP dr Kariadi, Semarang. Juru bicara RSUP dr Kariadi, Semarang, Jawa Tengah menyampaikan bahwa terlepas dari jumlah alat perlindungan diri (APD) yang terus bertambah, ada hal lain yang dapat menyebabkan para tenaga kesehatan terpapar oleh virus Covid-19 yaitu ketidakjujuran pasien dalam menyampaikan keadaannya. Hal tersebut membuat kewaspadaan yang dilakukan oleh para tenaga kesehatan berkurang hingga akhirnya para tenaga kesehatan terpapar oleh virus (Ernes, 2020).

Hal lain yang dialami oleh para tenaga kesehatan selama masa pandemi Covid-19 adalah sulitnya bertemu dengan keluarga. Sebagai orang yang berinteraksi dengan ODP, PDP, bahkan pasien yang positif, kekhawatiran yang dialami oleh para tenaga kesehatan adalah menjadi pembawa virus bagi keluarga. Hal itu membuat para tenaga kesehatan harus mengisolasi diri dan tidak bertemu dengan keluarganya. Seperti yang dikutip dari media, Kapten Fitdy, Ketua Tim Satgas COVID-19 Rumah Sakit Darurat Wisma Atlet dari angkatan militer menyampaikan bahwa ia dan para tenaga kesehatan lain terpaksa harus dikarantina dan tidak bisa bertemu dengan anggota keluarga lainnya hingga waktu yang belum diketahui (Satuan Tugas Penanganan Covid-19, 2020).

Tantangan yang dihadapi oleh tenaga kesehatan semakin bertambah dengan adanya wacana akan segera dilakukannya the new normal di Indonesia. Terjadi pro kontra menanggapi wacana tersebut. Berbagai pihak menilai bahwa konsep new normal terlalu dini untuk dilakukan di Indonesia. Hal itu berkaitan dengan kurva kejadian Covid-19 yang belum mengalami penurunan. Wacana the new normal dirasa akan makin menambah beban para tenaga kesehatan. Ketua Persatuan Perawat Nasional Indonesia (PPNI), Harif Fadhillah mengkhawatirkan akan terjadi eskalasi kasus ketika new normal diberlakukan dimana jika terjadi peningkatan kasus maka tenaga kesehatan pulalah yang akan menjadi ujung tombak. Hal itu akan berdampak pula pada semakin lama para tenaga kesehatan harus menjalankan tugas menangani kasus Covid-19 (Margianto, 2020). 
Berbagai macam permasalahan yang muncul selama pandemic Covid-19 menjadi tantangan besar bagi tenaga kesehatan. Berbagai permasalahan psikologis dapat muncul akibat pandemic covid-19. Permasalahan psikologis tersebut bisa berupa meningkatnya tingkat stress yang dialami oleh para tenaga kesehatan. Sarafino mendefinisikan stres sebagai keadaan yang disebabkan oleh interaksi antara individu dengan lingkungan yang menimbulkan adanya persepsi terhadap tuntutan-tuntutan dari sebuah situasi yang kemudian berdampak pada sistem biologis, psikologis, dan sosial dari seseorang. Stres bersifat individual dan pada dasarnya bersifat merusak bila tidak ada keseimbangan antara daya tahan mental individu dengan beban stres yang dirasakan.

Berdasarkan paparan yang telah disampaikan sebelumnya, peneliti tertarik untuk mengetahui bagaimana gambaran stres pada tenaga kesehatan selama masa pandemi Covid-19.

\section{METODE PENELITIAN}

Subjek dalam penelitian ini adalah tenaga kesehatan baik yang terlibat langsung maupun tidak langsung dalam penanganan Covid-19. Pengambilan sampel dilakukan secara online melalui google form dengan menggunakan convenience/incidental sampling.
Pengambilan data dilakukan dengan google form dibagikan via media sosial baik whatsapp, instagram, maupun media sosial yang lain.

\section{Pendekatan, Instrumen, dan Analisis}

\section{Data Penelitian}

Penelitian ini merupakan penelitian deskriptif yang bertujuan untuk melihat gambaran stres pada tenaga kesehatan selama masa pandemic Covid19. Data kuantitatif dari penelitian ini dikumpulkan melalui skala depression anxiety stress scale (DASS-21). Pengambilan data dilakukan melalui google form yang dibagikan via media sosial.

\section{Analisis Data}

Teknik analisis pada penelitian ini menggunakan analisis deskriptif untuk memberikan gambaran umum mengenai stress pada tenaga kesehatan yang terlibat pada penanganan Covid-19 selama masa pandemi. Peneliti juga akan melakukan analisis terhadap pertanyaan terbuka yang diberikan kepada partisipan.

\section{HASIL DAN PEMBAHASAN Hasil Penelitian}

Jumlah responden pada penelitian ini berjumlah 101 tenaga kesehatan. Berikut ini akan diuraikan secara lebih detail data demografis dari tenaga kesehatan yang menjadi responden penelitian: 
Tabel 1. Karakteristik Responden Berdasarkan Usia

\begin{tabular}{ccc}
\hline Kategori & F & \% \\
\hline $21-30$ Tahun & 64 & 63,4 \\
$31-40$ Tahun & 30 & 29,7 \\
$41-50$ Tahun & 5 & 5,0 \\
$>$ 50 Tahun & 2 & 2,0 \\
\hline Total & 101 & 100 \\
\hline
\end{tabular}

Tabel 2. Karakteristik Responden

Berdasarkan Jenis Kelamin

\begin{tabular}{ccc}
\hline Kategori & F & \% \\
\hline Laki-laki & 15 & 14,9 \\
Perempuan & 86 & 85,1 \\
\hline Total & 101 & 100 \\
\hline
\end{tabular}

Tabel 3. Karakteristik Responden Berdasarkan Jenis Pendidikan

\begin{tabular}{ccc}
\hline Kategori & F & \% \\
\hline SMK & 64 & 4,0 \\
D3 & 43 & 41,6 \\
D4 & 2 & 2,0 \\
S1 & 46 & 54,5 \\
S2 & 6 & 5,9 \\
\hline Total & 101 & 100 \\
\hline
\end{tabular}

Tabel 4. Karakteristik Responden Berdasarkan Pekerjaan

\begin{tabular}{ccc}
\hline Kategori & F & \% \\
\hline Perawat & 45 & 44,6 \\
Dokter & 14 & 13,9 \\
Apoteker / Farmasi & 17 & 16,8 \\
Lainnya & 25 & 24,8 \\
\hline Total & 101 & 100 \\
\hline
\end{tabular}

Tabel 5. Karakteristik Responden

Berdasarkan Lokasi Kerja

\begin{tabular}{ccc}
\hline Kategori & F & \% \\
\hline RS & 69 & 68,3 \\
Puskesmas & 23 & 22,8 \\
Klinik & 6 & 5,9 \\
Apotek & 1 & 1,0 \\
Lainnya & 2 & 2,0 \\
\hline Total & 101 & 100 \\
\hline
\end{tabular}

Tabel 6. Karakteristik Responden Berdasarkan Lama Bekerja

\begin{tabular}{ccc}
\hline Kategori & F & \% \\
\hline$<1$ Tahun & 12 & 11,9 \\
$1-5$ Tahun & 49 & 48,5 \\
$6-10$ Tahun & 28 & 27,7 \\
$11-15$ Tahun & 7 & 6,9 \\
$>15$ Tahun & 5 & 5,0
\end{tabular}

\begin{tabular}{lll}
\hline Total & $101 \quad 100$ \\
\hline
\end{tabular}

Tabel 7. Karakteristik Responden Berdasarkan Status Pekerjaan

\begin{tabular}{ccc}
\hline Kategori & $\mathbf{F}$ & $\mathbf{\%}$ \\
\hline Tetap & 52 & 51,5 \\
Kontrak & 49 & 48,5 \\
\hline Total & 101 & 100 \\
\hline
\end{tabular}

Tabel 8. Karakteristik Responden Berdasarkan Status Pernikahan

\begin{tabular}{ccc}
\hline Kategori & F & \% \\
\hline Belum Menikah & 40 & 39,6 \\
Menikah & 59 & 58,4 \\
Kawin Cerai & 2 & 2,0 \\
\hline Total & 101 & 100 \\
\hline
\end{tabular}

Tabel 1.9. Karakteristik Responden Berdasarkan Jumlah Anak

\begin{tabular}{ccc}
\hline Kategori & F & \% \\
\hline Belum Punya & 57 & 56,4 \\
1 Anak & 22 & 21,8 \\
2 Anak & 17 & 16,8 \\
$>3$ Anak & 5 & 5,0 \\
\hline Total & 101 & 100 \\
\hline
\end{tabular}

Tabel 10. Karakteristik Responden Berdasarkan Tinggal

\begin{tabular}{ccc}
\hline Kategori & F & \% \\
\hline Sendiri & 19 & 18,8 \\
Keluarga & 77 & 76,2 \\
Lainnya & 5 & 5,0 \\
\hline Total & 101 & 100 \\
\hline
\end{tabular}

Tabel 11. Karakteristik Responden Berdasarkan Terlibat Penanganan

\begin{tabular}{ccc}
\hline Kategori & $\mathbf{F}$ & $\mathbf{\%}$ \\
\hline Ya & 63 & 62,4 \\
Tidak & 38 & 37,6 \\
\hline Total & 101 & 100 \\
\hline
\end{tabular}

Analisis data yang digunakan berupa analisis deskriptif yaitu analisis data yang berfungsi untuk mendiskripsikan karakteristik sampel penelitian, memeriksa variabel dari kesalahan dalam asumsi penggunaan 
teknik statistik yang nantinya digunakan untuk menjawab pertanyaan penelitian, dan memastikan pertanyaan penelitian tersebut spesifik (Pallant, 2011). Analisis statistik deskriptif meliputi pengujian mean, range, standar deviasi, skewness, dan kurtosis (Pallant, 2011). Penyajian data dalam statistik deskriptif dapat berupa tabel, grafik, diagram, dan pikogram. Pada penelitian ini, analisis statistik deskriptif disajikan dalam bentuk tabel.

Analisis statistik deskriptif menggunakan bantuan SPSS 20 for Windows. Berikut adalah hasil analisis statistik deskriptif untuk alat ukur DASS.

Hasil analisis statistik deskriptif untuk alat ukur DASS:

Tabel 12. Analisis Deskriptif Alat Ukur DASS

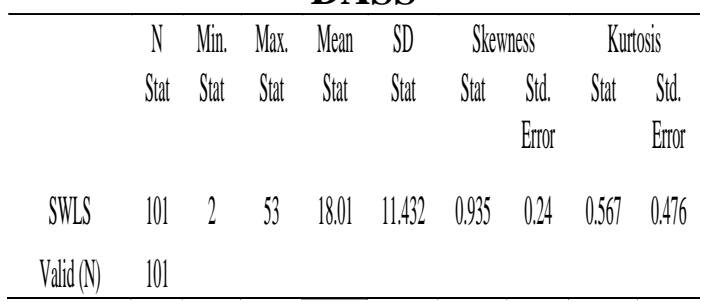

Penjelasan mengenai nilai minimal, maksimal, mean, dan standar deviasi digunakan untuk mendiskripsikan karakteristik sampel (Pallant, 2011). Tabel Min dan Max ditujukan untuk mengetahui jumlah nilai terendah dan tertinggi dari masing-masing jawaban responden terhadap variabel penelitian. Kemudian tabel Mean menunjukkan nilai rata-rata.
Nilai pada tabel skewness mengindikasikan kesimetrisan dan distribusi data (Pallant, 2011). Distribusi data normal diperoleh jika skewness adalah $0 . \quad$ Nilai skewness (-) mengindikasikan data menyimpang ke arah negatif. Sedangkan nilai skewness (+) mengindikasikan data menyimpang ke arah positif. Nilai pada tabel kurtosis menunjukkan besar kecilnya sebaran data (Pallant, 2011). Distribusi data yang sangat normal, yaitu distribusi tidak terlalu tinggi dan tidak terlalu rendah akan memiliki nilai kurtosis 0 . Apabila nilai kurtosis (+) menunjukkan bahwa skor mengumpul di tengah, sehingga kurva normal membentuk gunung yang sangat tinggi. Kemudian nilai kurtosis (-) membentuk kurva normal yang cenderung mendatar.

Berdasarkan hasil analisis statistik deskriptif alat ukur DASS diatas maka diperoleh bahwa skor minimal yang diperoleh adalah 2 sedangkan skor maksimal yaitu 53. Selanjutnya untuk mean dan standar deviasi yang diperoleh masing-masing yaitu 18.01 dan 11.432. Nilai skewness dan kurtosis berada pada angka 0 , sehingga menunjukkan bahwa distribusi data normal.

Analisis juga dilakukan untuk melihat bagaimana tingkatan subjective well-being yang dimiliki para responden, 
maka seluruh responden digolongkan dalam tiga kategori yaitu tinggi, sedang, dan rendah dengan ketentuan sebagai berikut:
a. Tinggi $=X>($ Mean $+1 \mathrm{SD})$
b. Sedang $=($ Mean -1 SD $)<X<$ $($ Mean +1 SD)

c. Rendah $=\mathrm{X}<($ Mean $-1 \mathrm{SD})$

Tabel 13. Penormaan DASS

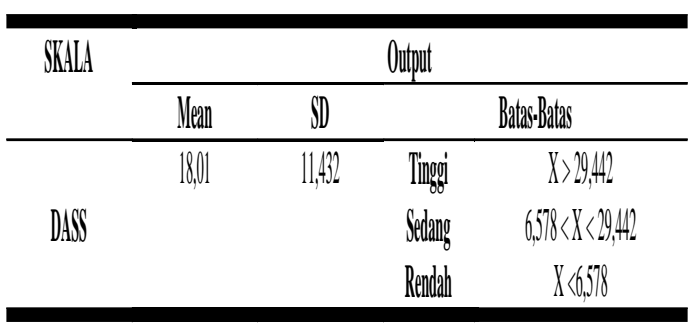

Tabel 14. Kecenderungan Depresi dan Stres berdasarkan DASS

\begin{tabular}{ccc}
\hline Depresi dan Stres & Jumlah Responden & Persentase \\
\hline Tinggi & 18 & $17,9 \%$ \\
Sedang & 68 & $67,3 \%$ \\
Rendah & 15 & $17,8 \%$ \\
Total & $\mathbf{1 0 1}$ & $\mathbf{1 0 0 \%}$ \\
\hline
\end{tabular}

Pada tabel 3.14 dapat kita lihat bahwa kecenderungan depresi dan stress pada para tenaga kesehatan ditinjau dari DASS sebagian besar responden dalam penelitian ini yaitu 68 dari 101 responden (67,3\%), memiliki tingkat kecenderungan depresi dan stres sedang, 18 dari 101 responden $(17,9 \%)$ memiliki tingkat kecenderungan depresi dan stress tinggi, dan 15 dari 101 orang responden $(17,8 \%)$ memiliki tingkat kecenderungan depresi dan stress rendah.

\section{Pembahasan}

Pandemi covid-19 memberikan dampak besar ke berbagai pihak karena merupakan suatu kejadian yang belum pernah dialami sebelumnya. Tenaga kesehatan sebagai pihak yang berkaitan erat dengan pasien covid-19 memiliki kerentanan baik dalam segi fisik maupun mental. Di sisi lain, memberikan dukungan pada tenaga kesehatan merupakan hal yang penting untuk dilakukan. Secara mental, mereka akan mengalami kekhawatiran akan tertularnya penyakit tersebut. Meskipun tidak terdampak langsung yang membuat mereka sakit, namun mereka dapat menjadi pembawa penyakit tersebut kepada orang lain utamanya adalah pihak keluarga. Hal tersebut dapat menimbulkan baik kecemasan, stress bahkan hingga kecenderungan depresi. Beban psikologis pada saat pandemic bertambah pada wanita, berprofesi sebagai perawat, berinteraksi secara langsung dengan pasien covid-19, memiliki status sosial ekonomi yang lebih rendah, dan menghabiskan lebih banyak waktu untuk melihat berita-berita terkait covid-19. Beberapa penelitian melaporkan dampak negatif yang muncul sebagai dampak dari pandemic Covid-19. Para tenaga kesehatan dilaporkan mengalami burnout, kelelahan mental, kecemasan, depresi, dan 
post traumatic stress disorder (Su, 2020).

Di sisi lain terdapat faktor pelindung selama pandemic covid-19 yaitu memiliki sumber daya medis yang memadai, memiliki informasi kesehatan yang mutakhir dan akurat, dan sudah melakukan tindakan pencegahan untuk menghindari penularan penyakit (Luo dkk, 2020).

Penelitian ini dilakukan pada 101 tenaga kesehatan baik yang terlibat langsung maupun tidak terlibat langsung dalam penanganan covid-19. Responden penelitian mayoritas berjenis kelamin perempuan $(85,1 \%)$ dan $14,9 \%$ lainnya adalah tenaga kesehatan laki-laki. Mayoritas $(63,4 \%)$ berada di kisaran usia 21-30 tahun. 62,4\% responden terlibat langsung dalam pengananan pasien covid19 sedangkan $37,6 \%$ tidak terlibat secara langsung dalam penanganan covid-19.

Berdasarkan hasil analisis terhadap kuesioner yang telah disebar kepada tenaga kesehatan, maka ditemukan bahwa para tenaga kesehatan memiliki tingkat stress pada kategori sedang. Hal ini menunjukkan bahwa mereka mengalami kekhawatiran terhadap kondisi kesehatan yang ada saat ini akibat dari pandemi covid-19. Hal ini sesuai yang dipaparkan oleh Handayani, dkk., (2020) bahwa tenaga kesehatan mengalami kekhawatiran pada masa pandemik covid-
19 ini dikarenakan adanya peningkatan resiko terpapr, terinfeksi dan kemungkinan menginfeksi orang lain terutama pada orang-orang terdekat yang akhirnya menjadi beban tersendiri. Mereka pun juga harus rela untuk melakukan isolasi diri dari keluarga dan orang-orang terdekat meski tidak mengalami covid-19.

Penelitian sejalan juga dilakukan oleh Wu, dkk., (2020) dengan penelitian berada di China yaitu menunjukkan hasil bahwa tenaga medis di China memiliki stres psikologis yang lebih tinggi dibandingkan dengan mahasiswa. Selanjutnya di Wuhan juga menunjukkan bahwa tenaga medis memiliki stres psikologis yang lebih tinggi dibandingkan mahasiswa. Kemudian antara tenaga medis di antara provinsi-provinsi di China menunjukkan bahwa tenaga medis di Wuhan memiliki tingkat stres psikologis yang lebih tinggi dibandingkan dengan yang lain, terutama terkait dengan kekhawatiran karena berada dalam lingkungan yang berbahaya, kemungkinan akan penyakit terhadap diri sendiri, kekhawatiran dapat menularkan kepada keluarga.

Hasil analisis secara kualitatif juga menunjukkan bahwa para tenaga kesehatan mengalami perasaan cemas, khawatir, dan was-was dalam 
menjalankan tugasnya. Berbagai macam hambatan dan tantangan yang muncul selama menjalankan tugas di masa pandemic Covid-19 membuat para tenaga kesehatan merasa tidak tenang dan tidak nyaman saat bertugas. Beberapa responden mengaku mengalami burnout dalam pekerjaanya. Mereka mengalami kelelahan karena harus bekerja keras menangani pasien sedangkan mereka sendiri tidak mengetahui kapan pandemi ini akan berakhir.

$$
\text { Berbagai macam hambatan }
$$
dihadapi oleh para tenaga kesehatan. Hal itu terkait dengan saat menggunakan APD, para tenaga kesehatan menjadi tidak leluasa dalam melakukan kegiatannya. APD yang digunakan membuat para tenaga kesehatan merasa kegerahan dan kesulitan dalam bergerak. Di sisi lain, para responden juga mengeluhkan jumlah APD yang terbatas. Para responden mengalami ketakutan akan tertular penyakit Covid19. Terlebih lagi, responden merasa bahwa masyarakat masih banyak yang belum dapat mematuhi protocol kesehatan yang berlaku. Masyarakat juga seringkali tidak berkata jujur saat melakukan pemeriksaan sehingga hal itu menambah resiko tenaga kesehatan akan tertular penyakit menjadi semakin besar. Kekhawatiran yang dialami responden menjadi bertambah ketika melihat keadaan diri dan keluarganya. Beberapa responden menjalankan tugas dalam keadaan hamil. Responden lain mengaku mengalami ketakutan ketika harus pulang ke rumah dan bertemu keluarga. Responden takut akan menjadi pembawa virus dan menularkan penyakit pada keluarga. Beberapa responden akhirnya melakukan isolasi diri untuk melindungi keluarga dari penularan penyakit dimana isolasi yang mereka lakukan itu juga membuat mereka dalam keadaan tidak nyaman dan merindukan keluarga.

Hal yang membuat para responden bertahan dengan pekerjaannya antara lain karena tuntutan ekonomi yang mengharuskan mereka untuk bekerja. Lingkungan dan rekan kerja yang nyaman dan saling mendukung satu lain juga memiliki peran dalam membuat beberapa responden bertahan dengan pekerjaannya. Hal lain yang membuat para tenaga kesehatan bertahan dalam menjalankan tugas adalah karena profesionalisme mereka. Para responden merasa bertanggung jawab pada profesi yang dijalani terlebih lagi mereka merasa terikat dengan sumpah profesi yang sudah mereka lakukan. Responden merasa memiliki amanah untuk menjalankan tugas mereka dan di sisi lain panggilan hati mereka juga mendorong untuk menolong para pasien yang membutuhkan 
bantuan. Hal itulah yang kemudian membuat mereka bertahan dalam menjalankan profesi meskipun harus menghadapi berbagai macam tantangan dan kesulitan yang ada.

\section{Ucapan Terima Kasih}

Penulis mengucapkan terima kasih kepada Lembaga Penelitian dan Pengabdian Masyarakat (LPPM) Universitas 17 Agustus 1945 (UNTAG) Surabaya yang telah mendukung dan memfasilitasi jalannya penelitian ini.

\section{PENUTUP}

Hasil penelitian ini menunjukkan bahwa sebagian besar responden penelitian yang merupakan tenaga kesehatan memiliki tingkat stres pada kategori sedang. Hasil analisis lebih lanjut menunjukkan bahwa para tenaga kesehatan mengalami rasa cemas takut akan tertular penyakit saat menjalankan tugas. Hambatan yang dialami pada saat menjalankan tugas terkait Alat Perlindungan Diri (APD) yang terbatas, rasa cemas akan tertular dan menularkan penyakit dan pasien yang kurang kooperatif. Namun begitu, responden penelitian ini tetap bertahan dengan pekerjaannya karena beberapa faktor antara lain kebutuhan ekonomi, lingkungan kerja yang nyaman, dan profesionalisme pekerjaan.

\section{DAFTAR PUSTAKA}

Budiansyah, A. (2020). Mengenal Apa Itu Virus Corona dan Cirinya Versi WHO. Diakses dari https://www.cnbcindonesia.com/tec $\mathrm{h} / 20200330102940-37$ 148375/mengenal-apa-itu-viruscorona-cirinya-versi-who

Cheung, T., Fong, T. K., \& Bressington, D. (2020). COVID-19 under the SARS Cloud: Mental Health Nursing during the Pandemic in Hong Kong. Journal of psychiatric and mental health nursing.

Ernes, Y. (2020). Pemerintah Prihatin 57 Tenaga Kesehatan RSUP dr Kariadi Positif Corona. Diakses dari https://news.detik.com/berita/d4981857/pemerintah-prihatin-57tenaga-kesehatan-rsup-dr-kariadipositif-corona

Handayani, R.T., Kuntari, S., Darmayanti, A.T., Widiyanto, A., Atmojo, J.T. (2020). Faktor penyebab stres pada tenaga kesehatan dan masyarakat saat pandemic covid-19. Jurnal Keperawatan Jiwa, Vol. 8, No. 3, Hal 353-360

Luo Min., Guo L., Yu. M., Jiang. W., Wang. H. (2020). The Psychological And Mental Impact Of Coronavirus Disease 2019 (COVID-19) On Medical Staff And General Public A Systematic Review And MetaAnalysis. Psychiatry Research 291, 113190.

Ma, Y., Rosenheck, R., \& He, H. (2020). Psychological stress among health care professionals during the 2019 novel coronavirus disease outbreak: cases from online consulting customers. Intensive and Critical Care Nursing, 102905.

Meilisa, H. (2020). 46 Tenaga Kesehatan di Jawa Timur Terpapar Virus 
Corona. Diakses dari

https://news.detik.com/berita-jawa-

timur/d-4980324/46-tenaga-

kesehatan-di-jawa-timur-terpapar-

virus-corona

Pallant, J. (2011). SPSS survival manual: A step by step guide to data analysis using SPSS (4th edition). Australia: Allen \& Unwin.

Sarafino, E.P.(1998). Health Psychology : Biopsychosocial Interactions. Third Edition. United States of American: John Wiley \& Sonc, Inc

Satuan Tugas Penanganan Covid-19 (2020). Rindu Ingin Pulang, Perawat COVID-19 Ajak Masyarakat Taati Protokol Kesehatan. Diakses dari https://covid19.go.id/p/berita/rinduingin-pulang-perawat-covid-19ajak-masyarakat-taati-protokolkesehatan

$\mathrm{Su}$ Ju-Cchuan., Shen Lih-Jong., Chen Hsiu-Chin. (2020). Maintaining Mental Health Among Medical Staff During The COVID-19 Pandemic: Taiwan's Experience. Journal of the Formosan Medical Association.

Talaee, N., Varahram, M., Jamaati, H., Salimi, A., Attarchi, M., Sadr, M., ... \& Seyedmehdi, S. M. (2020). Stress and burnout in health care workers during COVID-19 pandemic: validation of a questionnaire. Zeitschrift fur Gesundheitswissenschaften $=$ Journal of Public Health, 1-6.

Wu, W., Zhang, Y., Wang, Pu., Zhang, L., Wang, G., Lei, G., Xiao, Q., Cao, X., Bian, Y., Xie, S., Huang, F., Luo, N., Zhang, J., Luo, M. (2020). Psychological stress of medical staffs during outbreak ogf covid-19 and adjustment strategy. Journal of Medical Virology, 1-9 